\title{
Discourse Markers in Argumentative Essay by the English Education Study Program's Students of Universitas Bengkulu: A Cross-sectional Study
}

\author{
Khamidah Sulistiya Rini Nurman \\ English Education Study Program, Department of Language and Art \\ Universitas Bengkulu \\ khamidahs@xlfutureleaders.com \\ Safnil Arsyad \\ English Education Study Program, Department of Language and Art \\ Universitas Bengkulu \\ safnilarsyad@gmail.com \\ Zahrida \\ English Education Study Program, Department of Language and Art \\ Universitas Bengkulu \\ zahrida@yahoo.com
}

\begin{abstract}
This research is aimed to find the most frequent type of discourse markers used in the argumentative essay and the differences in its use written by the first, third, and fifth semester students of English Education study program of Universitas Bengkulu. The documentation technique and checklist are used in this research. Thirty two argumentative essays written by English Education Study Program's students were analyzed by using mix method quantitative and qualitative, along with descriptive approach. The results showed that the most frequent type of discourse markers used by English Education students is additive markers (58\%). And the students have different amount of discourse markers in their writing where the third semester students used more discourse markers than the other two group of students (148). It is highly encouraged for English Education instructors to take teaching discourse markers specifically into account. It is also suggested for future researchers to further analyze the correct use of discourse markers in the argumentative essay written by English Education Study Program students of Universitas Bengkulu.
\end{abstract}

Key Words: Argumentative essay, discourse markers, English students.

\begin{abstract}
Abstrak
Penelitian ini bertujuan untuk mengetahui jenis penanda wacana bahasa yang paling sering digunakan dalam esai argumentatif Bahasa Inggris dan perbedaan yang terjadi dalam penggunaanya oleh mahasiswa semester pertama, ke-tiga, dan ke-lima. Penelitian ini menggunakan teknis ceklis table dan dokumentasi. Tiga puluh dua esai argumentative dalam bahasa Inggris yang ditulis oleh mahasiswa program studi Bahasa Inggris dianalisa menggunakan metode kuantitatif dan kualitatif gabungan dengan pendekatan deskriptif. Hasil penelitian ini menunjukkan bahwa jenis penanda wacana yang paling sering digunakan oleh mahasiswa program studi pendidikan Bahasa Inggris adalah penanda wacana aditif. Kemudian perbedaan ditemukan pada jumlah penanda wacana yang digunakan oleh $\mathrm{m}$ mahasiswa program
\end{abstract}


studi Bahasa Inggris, mahasiswa semester tiga menggunakan lebih banyak penanda wacana dalam tulisannya dibandingkan dengan dua kelompok mahasiswa yang lain. Sangat dianjurkan bagi instruktur program Pendidikan Bahasa Inggris untuk mengajarkan materi penanda wacana secara spesifik dan serius. Peneliti selanjutnya disarankan untuk meneliti lebih jauh terkait penggunaan penanda wacana yang tepat oleh mahasiswa program studi pendidikan Bahasa Inggris Universitas Bengkulu.

Kata Kunci: Esai argumentatif, mahasiswa Bahasa Inggris, penanda wacana

\section{Introduction}

Writing depends on individuals' ability of using proper written language to express their thoughts and feelings. It takes a person to create a consistent and meaningful text in a right form. Text is a consistent and meaningful structure formed by words, sentences, and paragraphs coming together, it proves the important of using language tools to improve the quality of writings. According to Rababa'h (2005) in EFL country, students have to face the difficulties in writing because of the lacking of using discourse markers (DMs) is one of the factors.

Schiffrin (1987) defines discourse markers (DMs) as the linguistics elements signaling the relation between unit of language, relations at the exchange, action, ideational, and participation framework levels of the discourse. She explained that they include a broad class of discourse markers conjunctions, interjections, adverbs, and lexicalized phrases.

Additionally, she said it can facilitate readers' comprehension and help to smooth the interaction between the writer and reader.

However, even if DMs became one of the most important aspects in writing, most of the EFL Learners have very little knowledge about the elements ofwriting such as discourse markers coherence, and cohesion between each paragraph and appropriate diction. It is quite difficult for the students to achieve the good writing performance, though they know their writing performance is important as one of the element that will decide whether or not they able to take the final step to conduct a research and writing their thesis. Actually it is better not to overgeneralize the absence of DMs in students writing because there are certain 
common types of DMs used by the students anyway, but whether the students are aware of using these language tools or not is still questionable.

The lack of DMs proper use in Indonesian writing context exactly becomes the first reason that motivate the researcher to decide to make DMs as her research topic, minding the fact that it what makes students having difficulties on fluently sending their writing intended message. Regardless its importance, as Alwasilah (2001) stated that DMs are rarely being taught cause the students get the information about DMs at least in two ways, self-learning or self-acquiring from the other subjects as writing or structure. Thus, it is really important to see whether their skill undergo the significant enhancement or even derivation.

In status quo research under the topic of discourse markers (DMs) as its topic is progressing, it is proved by the number of research which has been done in these past decades which is increasing. Firstly, it can be seen from Larasati (2018) who tried to analyze the DMs use in Sanata Darma Univeristy Yogyakarta's students argumentative and expository essay. She found out that the common type of DMs use in the elaborative markers, also the inappropriateness were mostly overusing, wrong relating, and semantic incompleting. Rahimi's (2011) did the study on DMs use of Iranian EFL students and found the extensive use of marker and happened in argumentative essay might imply that the use of Elaborative (Additive) DMs is more closely related to argumentative compositions than other DMs due to the fact that this writing in general requires explanation of ideas, which depends to a large extent on the use of Elaborative (Additive) DM to establish a kind of parallel relationships between different sections of the written discourse. Also Al-Yaari (2013) research under the title Using English Discourse Markers (DMs) by Saudi EFL Learners: A Descriptive Approach. The results of his research illustrated that DMs "and" was the most frequent DMs in the writing of Saudi EFL learners. These devices were randomly used by Saudi EFL learners who mix their use (appropriateness) with usage (correctness) due to the influence of their $L 1$ 
(Arabic). In compare to the other EFL learners (native and non-native), Saudi EFL learners use less DMs. These results confirmed the claims

In addition, Vyatkina (2012) who did the cross-sectional study on college-level learners of German over four semesters of study beginning at the novice level found that the learners follow some general developmental trends established in term of fluency and accuracy of using DM. The students coming from the higher level of education tend to use more various and accurate DMs than the other group of students.

What different in this research to those previous researches is the sample who are the English Education Study Program Students from first, third, and fifth semester of University of Bengkulu. Moreover, it will not stop analyzing the DMs use only, but also the cross-sectional findings among three different group of students. Therefore, this research had two research question were "What type of DMs is the most frequently used by the first, third, and fifth semester students of English Education Study Program of Universitas Bengkulu's argumentative essay? and What is the difference if any on the use of DMs between the first, third and fifth semester students of English Education Study Program of Universitas Bengkulu's argumentative essay?" The researcher hopes this research will give some influences to the students, the researchers and the future researchers.

\section{Method}

The qualitative and quantitative or mixed method will be used in this research, Johnson and Christensen (2004) defined it as a study involves the collection or analysis of both quantitative and qualitative data in a single study with some attempts to integrate the two approaches one at one or more stages of the research processes.

The researcher chose this design because it was the most appropriate design related to the problem which is going to be discussed.

The population of this research were the 253 students includes 73 students from first semester, 101 students from third semester, and 79 students from fifth semester of English Education Study Program of 
Universitas Bengkulu. The normal distribution sampling proposed by Hatch and Lazatron, (1991) where in a research containing quantitative elements, a statistical consideration which include at least 30 people which means equal to $12.5 \%$ of the total population is used. The students who wrote the essays were randomized. In this research, the corpuses were 32 essays written by the students which distribution were as follow; 9 essays from first semester students, 13 and 10 essays for third and fifth semester students.

The instruments used in this research were the argumentative composition writing to be assigned to students to write on the topics, selected by the researchers. Then, to know the type of the discourse markers (DMs) found in the students' essay, the researcher used the checklist table instrument based on the model which Mackay (1987) proposed. Particularly, the table consisted of six categories of DMs which were Enumerative, Additive, Logical Sequence, explicative, Illustrative and Contrastive. This checklist table was integrated into statistical formula to calculate the frequency of certain type of DMs found.

To achieve the purpose of the research, the following steps were taken during the research process: the students were asked to write the argumentative essay based on the topic which had been assured by expert judgment. It was given similarly to the first, third, and fifth semester students. Then, after the required number of corpuses were gotten, the hand-written essays were converted into the digital document. The discourse markers (DMs) in the essays were identified. Then, the types of discourse markers found in the essays were classified based on the DMs type Mackay (1987) proposed. Lastly, the frequencies were calculated by Excel. A co-rater was also used to ensure the reliability of the findings, the co-rater was asked to analyze the corpus of the question and answer (discussion) was used. To find out if the person can analyze the DMs type occur in students' essays. 


\section{Result and Discussion}

\section{Result}

There are 320 discourse markers (DMs) found in 32 argumentative essays consisted of 7,008 words written by the first, third, and fifth semester students. It is found that the Additive DMs is the answer. Below is the table showing the frequency of DMs use based on its type.

Table 1. Type of DMs Used Frequently in Students' Argumentative Essay

\begin{tabular}{|l|c|c|}
\hline \multicolumn{1}{|c|}{ Type } & $\Sigma$ & $\%$ \\
\hline Enumerative & 31 & $10 \%$ \\
\hline Additive & 186 & $58 \%$ \\
\hline Logical Sequence & 39 & $12 \%$ \\
\hline Explicative & 1 & $0.003 \%$ \\
\hline Illustrative & 11 & $3 \%$ \\
\hline Contrastive Total & 52 & $16 \%$ \\
\hline & 320 & $100 \%$ \\
\hline
\end{tabular}

Table 1 presents the number of DMs that are used by the students. The most frequent DM used by the student with total number of 186 is the Additive DMs (58\%). The second most frequent type of DMs used with 52 of total amount found in students' essay is the Contrastive DMs (16\%). The third most frequent DM used by the students is the Logical Sequence DMs. Where basically, there are 39 or $12 \%$ Logical Sequence DMs have been discovered in students' essays. The fourth most frequent DMs used by the students in their argumentative essays are the Enumerative DMs, there are 31 Enumerative DMs found or 10\% over all DMs found in students' essays. The fifth most frequent type of DMs used by students are the Illustrative DMs, there are 11 Illustrative DMs found in students' essay or $3 \%$ over the total use of DMs The least type of DMs used the most by the students is the Explicative DMs, there is 1 marker found in students' essay which equal to $0.003 \%$ over the total DMs use found. 
Meanwhile, the differences happen in DM use between three groups of students will be presented as well. Below is the table showing the result.

Table.2 Type of DMs Used in First, Third, and Fifth Semester Students

\begin{tabular}{|l|c|c|c|c|c|c|c|c|}
\hline \multirow{2}{*}{ Type } & \multicolumn{2}{|c|}{ 1st SMT } & \multicolumn{2}{|c|}{ 3rd SMT } & \multicolumn{2}{|c|}{ 5th SMT } & \multicolumn{2}{|c|}{ Total } \\
\cline { 2 - 9 } & $\Sigma$ & $\%$ & $\Sigma$ & $\%$ & $\Sigma$ & $\%$ & $\Sigma$ & $\%$ \\
\hline $\begin{array}{l}\text { Enumerative } \\
\text { DMs }\end{array}$ & 6 & $10 \%$ & 13 & $9 \%$ & 12 & $11 \%$ & 31 & $7 \%$ \\
\hline Additive DMs & 36 & $59 \%$ & 76 & $51 \%$ & 74 & $66 \%$ & 186 & $58 \%$ \\
\hline $\begin{array}{l}\text { Logical } \\
\text { Sequence DMs }\end{array}$ & 7 & $11 \%$ & 22 & $15 \%$ & 10 & $9 \%$ & 39 & $12 \%$ \\
\hline Explicative DMs & 0 & $0 \%$ & 1 & $1 \%$ & 0 & $0 \%$ & 1 & $0 \%$ \\
\hline Illustrative DMs & 3 & $5 \%$ & 6 & $4 \%$ & 2 & $2 \%$ & 11 & $3 \%$ \\
\hline Contrastive DMs & 8 & $15 \%$ & 30 & $20 \%$ & 14 & $13 \%$ & 52 & $16 \%$ \\
\hline Total & 60 & $19 \%$ & 148 & $46 \%$ & 112 & $35 \%$ & 320 & $100 \%$ \\
\hline
\end{tabular}

As table 2 indicates the difference can be seen from the total number of DMs found in each semester students' essay. The students from third semester used more DMs compared to the first and fifth semester students. 148 DMs (46\%) over the total DMs used by the students are found in the third semester students' writing. Meanwhile, in the fifth semester students' essay which are expected to contained the highest numbers of DMs, there are 112 (35\%) DMs found or 36 DMs lesser compared to those found in the third semester students writing. The least number of DMs are found in the first semester students' essays. There are 60 (19\%) DMs found.

In this research, there are three main topics which are offered to the students to be argued in their argumentative essays which are: social media raising, death penalty for corruptor, and the Uang Kuliah Tunggal (UKT) as the tuition fee system 
Table. 3 Students' Writing's Topic Preferences

\begin{tabular}{|c|l|c|c|c|}
\hline No & \multicolumn{1}{|c|}{ Topic } & $\mathbf{1 s t}$ smt & 3rd smt & 5th smt \\
\hline 1 & Social Media & $56 \%$ & $46 \%$ & $50 \%$ \\
\hline 2 & Corruption & $44 \%$ & $31 \%$ & $30 \%$ \\
\hline 3 & Uang Kuliah Tunggal (UKT) & 0 & $2 \%$ & $20 \%$ \\
\hline
\end{tabular}

As table 3 indicates there is no significant difference on the topic chosen by three different groups of students. The first semester students mostly chose social media as their writing topic (56\%), followed by the corruption topic (44\%), and none choose Uang Kuliah Tunggal (UKT) as their topic.

The third semester students also mostly chose social media as their topic (46\%), social media (31\%), and Uang Kuliah Tunggal (UKT) (2\%). And similar to the first and third semester students, the majority of the fifth semester students chose social media (50\%) as their writing topic, followed by the corruption (30\%), and Uang Kuliah Tunggal (UKT) (20\%).

\section{Discussion}

The first finding is about the most frequent type of DM used by students in their argumentative essays, in this research the most frequent type of DM is Additive DM where 154 over 186 DMs found is the DM and. This is probably because Additive is used as a conjunction to connect two or more words in the same sentence. It means the students may have used the simple and easy DM in their writings and avoid the difficult one. According to Schachter (1974) when the second language learners are facing with language difficulties, the avoidance phenomenon will occur because they tend to give up the use of certain words or rules of language.

Regarding to that issue, Ellis (2003) argues, it is one of the strategies learners use when they want to overcome a communicative difficulty. What is avoided is a word or structure in the target language that the learner thinks is difficult and prefers to evade it with a parallel and easier word or structure. The students also might use the Additive DMs excessively 
because this $\mathrm{DM}$ is often being exposed to them. It might imply that the students tend to use the DM they are familiar with. As Murray (1990) contends, it is also possible that EFL students' extensive use of a marker is due to the fact that they are exposed and familiar to such markers in their own native language and in the English textbooks they read.

This is similar to the Rahimi's (2011) finding which found the extensive use of marker and happened in argumentative essay might imply that the use of Elaborative (Additive) DMs is more closely related to argumentative compositions than other DMs due to the fact that this writing in general requires explanation of ideas, which depends to a large extent on the use of Elaborative (Additive) DM to establish a kind of parallel relationships between different sections of the written discourse.

Furthermore, it is also in line with the result coming out from Larasati's (2018) research who found that the elaborative DM and is used the most in students essay. This is probably because of the influence of the type of text, which is argumentative essay. It means the students have tendency to elaborate the ideas more rather than concluding, giving reason, contrasting, inferring, and giving examples.

The second finding is about the difference of DMs use between three different groups of student. The result shows that most DMs are found in the third semester students' essay than the other two groups of students. This probably happens because the third semester students want to make their essay considered as good essays. They seem to be focusing on the number of the DMs they use. It means that there is a tendency of students overusing the DMs to make their composition seem more acceptable. Rothman (2008) argued that the EFL students while writing tend to have a tendency to rate a good writing based on its grammatical elements in which DMs is one of them.

Meanwhile, the fifth semester students who are expected to use the highest number of DMs than the other two groups in fact use lesser than the third semester students. This probably happens because of the long learning period they have. It means that, they seem to have awareness of the needs of their readers and control the strategies for making their texts

more considerate and reader friendly. And this is partly achieved through DMs. Halliday and Hassan (1976) argued that compositions with more DMs 
were considered as more cohesive though DMs are by no means the only evidence for a well-organized and cohesive text, and this could only be achieved if the writer is aware of what they write.

And the case that happens to the first semester students who used the least number of DMs in their writing probably happens because they are less experienced in writing compare to the other two groups. It means that they have lack knowledge in term of vocabulary, grammatical structure, and DMs itself. Halliday and Hassan (1976) farther claimed that writer's composition writing experience in the target language is also considered to be a source of difference in the groups' writings.

The differences might also happen because of the external factor, such as the choices of topic students have for their writing. However, in this research this claim is failed, because there is no significant differences regarding the topic choices related to the academic level as well as the absence of correlation in term of the number of DMs generated in each topic. May be this happened because the number of DMs varied due to the writer's background knowledge and experience. Ravid (2005) has argued, clause length and DMs variation derives from number and length of intraclausal phrases, which in turn reflect lexical density and diversity, combined with syntactic depth and diversity has no relation to the topic, but it is one of the factors which affect the author writing if only the topic related to the background knowledge owned by the writer.

\section{Conclusion and Suggestion}

Based on the findings, the conclusions are presented as follows. First, this research confirms the previous researches by Rahimi (2011) and Larasati (2018) that the most frequent type of DMs found in EFL students' argumentative essay is the elaborative (additive) DM, similar to the finding of this, though the DMs used by the students has lack of variation and dominated by the DM and. 
However, the second result of this research is different from Vyatkina's (2012) research, because instead of showing a positive trend of DMs use which is constantly rising and developing as the students' academic level continue, in this research the third semester students use more DMs than the first and fifth semester students in their essays, though three type of writing topics had been given to the students. Therefore, it can be conclude that there is no conclusive trend in DM use regarding students' academic level.

In relation to the conclusions, suggestions are given as the following. the English Study Program students are expected to use more varieties of DMs in their writing, since the variation of the DMs used by the students are limited to the additive DM, because it affects the discourse quality of the writing. Also, since this cross-sectional study is limited to look for the frequency of the use of DMs, the future researches could expand the research to look for the correctness of the students' use of DM.

\section{References}

Alwasilah, Saleh. (2013). Using English discourse markers (DMs) by Saudi EFL learners: a descriptive approach. International Journal of English Language Education Vol. 1, No. 2, Special Issue.

Al-Yaari B. (1999). What are discourse markers? Journal of Pragmatics, 31

Jhonson, A and Christense, S. (2004). Discourse markers in composition writing: the case of Iranian learners of English as a foreign language. English Language Teaching, L(2).

Larasati, Marcelina. (2018). The use of discourse markers on argumentative and expository essays in critical reading and writing I. Yogyakarta. Sanata Dharma University.

Lazatron, W. (1991). Dynamic approach to second language development. Methods and techniques. Philadelphia/Amsterdam: John Benjamins.

Rahimi, Mihammad. (2011). Discourse markers in argumentative and expository writing of iranian efl learners. World Journal of English Langugae, I(2), 68-78.

Schiffrin, D. (1987). Dscourse markers. Cambridge: Cambridge University Press. 
Vyatkina, Nina. (2012). The development of second language writing in groups and individuals: a longitudinal learner corpus students. University of Kansas. The Modern Language Journal, 96, 4.

McKay, G. (1987). Discourse markers and its function. The Linguistics Journal, 4

Ravid, P. (2005). Discourse markers and 12 acquisition. Papers in Applied Linguistics, 7

Rothman, R. (2008). Connectives and topic-fronting devices in academic writing: taiwanese efl student writers vs international writers. International Conference and Workshop on TEFL and Applied Linguistics.

Schachter, B. (1974). Research methods in applied linguistics; quantitative, qualitative, and mixed methodologies. Spain. Oxford University Press.

Writer Information

\begin{tabular}{|l|l|}
\hline Name & Khamidah Sulistiya Rini Nurman \\
\hline Affiliation & $\begin{array}{l}\text { English Education Study Program, Department of } \\
\text { Language and Art, Universitas Bengkulu }\end{array}$ \\
\hline Email & khamidahs@xlfutureleaders.com \\
\hline Phone Number & 081932395786 \\
\hline
\end{tabular}


